Contents lists available at Џournal IICET

JPPI (Jurnal Penelitian Pendidikan Indonesia)

ISSN: 2502-8103 (Print) ISSN: 2477-8524 (Electronic)

\title{
The role of transformational leadership, servant leadership, digital transformation on organizational performance and work innovation capabilities in digital era
}

\author{
Bestadrian Prawiro Theng ${ }^{1}$, Elyzabeth Wijaya ${ }^{1}$, Juliana Juliana ${ }^{\left.2^{*}\right)}$, Eddy Eddy ${ }^{3}$, Ali Syah Putra $^{3}$ \\ ${ }^{1}$ Institut Bisnis Informasi Teknologi dan Bisnis, Medan, Indonesia \\ ${ }^{2}$ Universitas Pelita Harapan, Tangerang, Indonesia \\ ${ }^{3}$ Universitas Pelita Harapan, Medan, Indonesia
}

\begin{tabular}{l} 
Article Info \\
\hline Article history: \\
Received Apr $18^{\text {th }}, 2021$ \\
Revised Jul $06^{\text {th }}, 2021$ \\
Accepted Aug $26^{\text {th }}, 2021$ \\
\hline
\end{tabular}

\section{Keyword:}

Transformational leadership Servant leadership Digital transformation

Organizational performance

Work innovation capabilities

\begin{abstract}
The purpose of this study is to analyze the relationship between Transformational Leadership, Servant Leadership, Digital Transformation on Organizational Performance and Work Innovation Capabilities. In this study using quantitative methods and data analysis techniques Structural Equation Modeling (SEM) using SmartPLS 3.0 software. This research was conducted in the population in this study were all SMEs in Tangerang City as many as 41,155 SMEs and based on the method of determining the number of samples according to Morgan, the sample units were 380 SMEs. Based on the results of data analysis transformational leadership has a significant effect on Organizational Performance, transformational leadership has no significant effect on Work Innovation Capabilities, servant leadership has a significant effect on Organizational Performance, servant leadership has no significant effect on work innovation capabilities, digital transformation has no significant effect on organizational performance, digital Transformation has no significant effect on Work Innovation Capabilities, organizational performance has no significant effect on work innovation capabilities, transformational Leadership has no significant effect on Organizational Performance through Work Innovation Capabilities, Servant Leadership has no significant effect on Organizational Performance through Work Innovation Capabilities, digital transformation has no significant effect significant to the Organizational Performance through Work Innovation Capabilities.
\end{abstract}

(C) 2021 The Authors. Published by IICET.

This is an open access article under the CC BY-NC-SA license (https://creativecommons.org/licenses/by-nc-sa/4.0)

\section{Corresponding Author:}

Juliana Juliana,

Universitas Pelita Harapan, Tangerang

Email: juliana.stpph@uph.edu

\section{Introduction}

The global Covid-19 pandemic that is endemic in all countries of the world has affected all sectors of people's lives. In Indonesia, almost all sectors are affected, especially the economic ecosystem which has been the focus of society. Furthermore, the Covid-19 pandemic has caused a slowdown in the economic sector in Indonesia with its various derivatives. The Micro, Small and Medium Enterprises (MSME) sector, which is the most important part of the economic sector, is greatly affected. This is what is worried by all parties, because it has made the MSME sector experience a significant setback. Moreover, currently many MSMEs are experiencing various problems such as declining sales, capital, hampered distribution, difficulty in raw materials, declining 
production and the occurrence of many layoffs for workers and workers which then become a threat to the national economy. According to Maroukian (2020) MSMEs as drivers of the domestic economy and absorber of labor are facing a decline in productivity which results in a significant decrease in profits. Even based on a survey by the Asian Development Bank (ADB) regarding the impact of the pandemic on MSMEs in Indonesia, $88 \%$ of micro-enterprises have run out of cash or savings, and more than $60 \%$ of these micro-small businesses have reduced their workforce. It must be admitted that the Covid-19 pandemic has reduced people's purchasing power. According to Quddus (2020) many consumers then keep their distance and switch purchases digitally. As a result, many MSMEs have to close their businesses due to declining purchases and are still dependent on offline sales. So that several MSME sectors that have not adapted digitally are ultimately very affected and closed their outlets. Even so, the Covid-19 pandemic has indirectly prompted new changes in Indonesia's business style. The change is the shift from offline business to digital business which is also known as the phenomenon of digital entrepreneurship. According to Fayaz (2017), Quddus (2020) Social media and market places (intermediaries) can be a concept to make it easier for MSME actors to get wider marketing access (Purwanto, 2019). It should be noted that MSMEs in Indonesia have become the most important pillar for the economic ecosystem. Moreover, it is known that 99\% of business actors in Indonesia are the MSME sector. According to El Toufaili (2017), Fayaz (2017), Quddus (2020) The role of MSMEs has contributed $60 \%$ to the national gross domestic product and $97 \%$ to the absorption of labor affected by the pandemic. Meanwhile, of the existing MSMEs, only 16 percent have entered the digital economy ecosystem. In the context of Indonesia, the MSME sector is one of the main pillars of Indonesia's economic fundamentals. In fact, during the 1998 economic crisis, it turned out that the MSME sector had a very positive contribution in saving the Indonesian economic ecosystem at that time. The same thing happened during the Covid-19 pandemic, where the MSME sector could have great potential to become an accelerator of national economic recovery. Therefore, an entrepreneurial model is needed that can adapt to technological advances. This is what gave birth to the digital entrepreneurship model. This business model comes from a combination of digital technology and entrepreneurship which then produces a new characteristic phenomenon in terms of business.

According to Fayaz (2017), Quddus (2020) Emerging technological paradigms harness the potential of collaboration and collective intelligence to design and launch stronger and more sustainable entrepreneurial initiatives. Even so, there are four dimensions related to digital entrepreneurship, namely digital actors (who), digital activities (what), digital motivation (why) and digital organizations (how). However, according to the records of the Ministry of Cooperatives and SMEs, currently there are 10.25 million MSME players who have been connected to digital platforms. According to. El Toufaili (2017), Fayaz (2017), Quddus (2020) The Covid-19 pandemic has made Micro, Small and Medium Enterprises (MSMEs) stagnant until some have had to close their outlets. This is due to changes in new habits with the implementation of health protocols which have an impact on the decline in people's purchasing power. In the context of the Indonesian economy, the Covid-19 pandemic can finally encourage the creation of a new ecosystem, namely digital entrepreneurship. In other words, this ecosystem has encouraged MSME actors to start transforming into the digital realm. Even so, the government has been trying to encourage the digitization program for MSMEs in Indonesia. This can be traced from the adaptation of MSME actors to use market places and social media in digital marketing.

The role of social media platforms has also become the main focus of MSME actors. In addition, MSME actors have also begun to adapt using various supporting applications such as digital financial platforms. According to Quddus (2020) Digital transformation of MSMEs during the Covid-19 pandemic can finally make MSMEs re-develop their businesses. Thus, the development of digital MSMEs during the Covid-19 pandemic can be an alternative to saving the MSME sector so that it continues to exist. However, efforts to develop digital SMEs must also be supported by the role of the government and the Ministry of Cooperatives and SMEs. Because MSME actors still need a lot of support, guidance and capital which incidentally comes from the government during the Covid-19 pandemic. If there is synergy between MSMEs, the government and other supporting stakeholders, it is certain that the MSME digital transformation process will be able to run perfectly. So that the government's target to increase digital-based MSMEs can be realized immediately. According to Gui (2021), Hernández (2020), Quddus (2020) the development of digital MSMEs after the Covid-19 pandemic must also be a top priority for the government and all stakeholders so that the digital economy ecosystem in Indonesia continues to run well. This is because the development of digital MSMEs will also contribute to strengthening the digital entrepreneurship ecosystem in Indonesia.

According to Hernández (2020), Kim (2020) The large number of MSME business actors illustrates that this sector has quite good potential in supporting the economy. The fairly good performance of these MSMEs contributes to the Gross Domestic Product (GDP) and employment. This is what underlies the increasing capacity of MSMEs, especially in facing the industrial era 4.0. The movement of the industrial revolution 4.0 which has echoed in recent years has an impact on changes in the way of working in various fields, especially in the business field. Business people are starting to use information technology and telecommunications to 
run and support their business activities. The movement and changes in the way of doing business that are increasingly fast towards digitalization are forcing business people to adapt to follow these changes. According to Fayaz (2017), Quddus (2020) for large companies, changes in business patterns that lead to the digitization process are not too constrained due to the characteristics of large companies that have good enough resources. However, for MSMEs this digitization process will require a lot of preparation. In order to encourage digitization and make it easier for MSMEs to deal with changes that occur, the government has increased the ease of access and transfers technology to MSME actors so that they can survive in business competition. The ability to master digital devices and the internet is an absolute thing that must be mastered by MSMEs if they want to survive in the competition. Research by Delloitte Access Economics (2015) states that consumers are increasingly accustomed to making decisions based on digital content and buying goods online. This is a challenge but also a promising business opportunity for MSMEs in Indonesia. Based on this, this research seeks to formulate a strategy for developing the digitization of MSMEs to support the development of MSMEs and as input for MSME actors in implementing digitalization in their business processes.

\section{Hypothesis Development \\ Relationship between Transformational Leadership and Organizational Performance}

Transformational Leadership Theory by Adwan et al. (2019) states that Transformational Leadership will have a positive influence on increasing Organizational Performance. According to research conducted by El Toufaili (2017), Fayaz (2017), Quddus (2020) states that increasing Transformational Leadership will encourage an increase in Organizational Performance variables. conducted by Purwanto et al. (2021) stated that an increase in the Transformational Leadership variable will encourage an increase in the Organizational Performance variable. According to research conducted by Fayaz (2017), Quddus (2020) states that Transformational Leadership has a significant influence on the Organizational Performance variable. Based on theoretical studies and previous studies, the following hypotheses are formulated:

Hypothesis 1: There is a positive influence between Transformational Leadership and Organizational Performance

\section{Relationship between Transformational Leadership and Work Innovation Capabilities}

Transformational Leadership Theory by Adwan et al. (2019) stated that Transformational Leadership will have a positive influence on increasing Work Innovation Capabilities. According to research conducted by Cheng et al. (2013), Christopher (2021), El-Gohary (2013) stated that an increase in Transformational Leadership will encourage an increase in the Work Innovation Capabilities variable. Meanwhile, research conducted by Purwanto et al. (2021) states that an increase in the Transformational Leadership variable will encourage an increase in the variable Work Innovation Capabilities. According to research conducted by Adwan et al. (2019); Bazazo et al. (2017) and Bui et al. (2006) stated that Transformational Leadership has a significant influence on the Work Innovation Capabilities variable. Based on theoretical studies and previous studies, the following hypotheses are formulated:

Hypothesis 2: There is a positive influence between Transformational Leadership and Work Innovation Capabilities

\section{Relationship between Servant Leadership and Organizational Performance}

Servant Leadership Theory by Adwan et al. (2019) states that Servant Leadership will have a positive influence on increasing Organizational Performance. According to research conducted by Gandolfi (2018), Burawat (2019) states that increasing Servant Leadership will encourage an increase in Organizational Performance variables. Meanwhile, research conducted by Purwanto et al. .(2021) states that an increase in the Servant Leadership variable will encourage an increase in the Organizational Performance variable. According to research conducted by Fayaz (2017), Quddus (2020) states that Servant Leadership has a significant influence on the Organizational Performance variable. Based on theoretical studies and previous studies, the following hypotheses are formulated:

\section{Hypothesis 3: There is a positive influence between Servant Leadership and Organizational Performance}

\section{Relationship between Servant Leadership and Work Innovation Capabilities}

Servant Leadership Theory by Adwan et al. (2019) states that Servant Leadership will have a positive influence on increasing Work Innovation Capabilities. According to research conducted by Burawat (2019), Gui (2021), Hernández (2020) states that increasing Servant Leadership will encourage an increase in the Work Innovation Capabilities variable. research conducted by Purwanto et al. (2021) states that an increase in the Servant Leadership variable will encourage an increase in the Work Innovation Capabilities variable. According to research conducted by El Toufaili (2017), Fayaz (2017), Quddus (2020) states that Servant Leadership has a significant influence on the Work Innovation Capabilities variable. Based on theoretical studies and previous studies, the following hypotheses are formulated: 
Hypothesis 4: There is a positive influence between Servant Leadership and Work Innovation Capabilities

\section{Relationship between Digital Transformation and Organizational Performance}

Digital Transformation Theory by Adwan et al. (2019) stated that Digital Transformation will have a positive influence on increasing Organizational Performance. According to research conducted by Cheng et al. (2013), Christopher (2021), El-Gohary (2013) stated that an increase in Digital Transformation will encourage an increase in Organizational Performance variables. Meanwhile, research conducted by Purwanto et al. (2021) states that an increase in Digital Transformation variables will encourage an increase in Organizational variables. Performance. According to research conducted by Adwan et al. (2019); Bazazo et al. (2017) and Bui et al. (2006) stated that Digital Transformation has a significant influence on the Organizational Performance variable. Based on theoretical studies and previous studies, the following hypotheses are formulated:

Hypothesis 5: There is a positive influence between Digital Transformation and Organizational Performance

\section{Relationship between Digital Transformation and Work Innovation Capabilities}

Digital Transformation Theory by Adwan et al. (2019) states that Digital Transformation will have a positive influence on increasing Work Innovation Capabilities. According to research conducted by E1 Toufaili (2017), Fayaz (2017), Quddus (2020) states that increasing Digital Transformation will encourage an increase in the Work Innovation Capabilities variable. Meanwhile, research conducted by Purwanto et al. (2021) states that an increase in the Digital Transformation variable will encourage an increase in the Work Innovation Capabilities variable. According to research conducted by Adwan et al. (2019); Bazazo et al. (2017) and Bui et al. (2006) stated that Digital Transformation has a significant influence on the Work Innovation Capabilities variable. Based on theoretical studies and previous studies, the following hypotheses are formulated:

Hypothesis 6: There is a positive influence between Digital Transformation and Work Innovation Capabilities

\section{Relationship between Organizational Performance and Work Innovation Capabilities}

Organizational Performance Theory by Adwan et al. (2019) stated that Organizational Performance will have a positive influence on increasing Work Innovation Capabilities. According to research conducted by Kim (2020). El Toufaili (2017), Fayaz (2017), Quddus (2020) state that an increase in Organizational Performance will encourage an increase in the Work Innovation Capabilities variable. Meanwhile, research conducted by Purwanto et al. (2021) states that an increase in the Organizational Performance variable will encourage an increase in the variable Work Innovation Capabilities. According to research conducted by Adwan et al. (2019); Bazazo et al. (2017) and Bui et al. (2006) stated that Organizational Performance has a significant influence on the Work Innovation Capabilities variable. Based on theoretical studies and previous studies, the following hypotheses are formulated:

Hypothesis 7: There is a positive influence between Organizational Performance and Work Innovation Capabilities

\section{Relationship between Transformational Leadership and Work Innovation Capabilities through Organizational Performance}

Transformational Leadership Theory by Adwan et al. (2019) stated that Transformational Leadership will have a positive influence on increasing Work Innovation Capabilities through Organizational Performance. According to research conducted by Cheng et al. (2013), Christopher (2021), El-Gohary (2013) stated that an increase in Transformational Leadership will encourage an increase in the Work Innovation Capabilities variable through Organizational Performance. Meanwhile, research conducted by Purwanto et al. (2021) states that an increase in the Transformational Leadership variable will encourage an increase in the Work Innovation Capabilities variable through Organizational Performance. According to research conducted by Adwan et al. (2019); Bazazo et al. (2017) and Bui et al. (2006) stated that Transformational Leadership has a significant influence on the Work Innovation Capabilities variable through Organizational Performance. Based on theoretical studies and previous studies, the following hypotheses are formulated:

Hypothesis 8: There is a positive influence between Transformational Leadership Organizational Performance through Work Innovation Capabilities

\section{Relationship between Servant Leadership and Work Innovation Capabilities through Organizational Performance}

Transformational Leadership Theory by Adwan et al. (2019) states that Servant Leadership will have a positive influence on increasing Work Innovation Capabilities through Organizational Performance. According to research conducted by Fayaz (2017), Quddus (2020) states that increasing Servant Leadership will encourage an increase in Work Innovation Capabilities through Organizational Performance. research conducted by Purwanto et al. (2021) states that an increase in the Servant Leadership variable will encourage an increase in the Work Innovation Capabilities variable through Organizational Performance. According to research conducted by Gandolfi (2018), Burawat (2019), Gui (2021) states that Servant Leadership has a 
significant influence on the Work Innovation Capabilities variable through Organizational Performance. Based on theoretical studies and previous studies, the following hypotheses are formulated:

Hypothesis 9 : There is a positive influence between Servant Leadership and Organizational Performance through Work Innovation Capabilities

\section{Relationship between Digital Transformation and Work Innovation Capabilities through Organizational Performance}

Digital Transformation Theory by Adwan et al. (2019) states that Digital Transformation will have a positive influence on increasing Work Innovation Capabilities through Organizational Performance. According to research conducted by El-Gohary (2013) states that increasing Digital Transformation will encourage an increase in Work Innovation Capabilities through Organizational Performance. conducted by Purwanto et al. (2021) stated that an increase in the Digital Transformation variable will encourage an increase in the Work Innovation Capabilities variable through Organizational Performance. According to research conducted by Maroukian (2020), Gandolfi (2018) states that Digital Transformation has a significant influence on the Work Innovation Capabilities variable through Organizational Performance. Based on theoretical studies and previous studies, the following hypotheses are formulated:

Hypothesis 10: There is a positive influence between Digital Transformation and Organizational Performance through Work Innovation Capabilities

\section{Method}

In this study using quantitative methods and data analysis techniques Structural Equation Modeling Equation Modeling using SmartPLS 3.0 software. This research was conducted in the population in this study were all MSMEs in Tangerang City as many as 41,155 MSMEs and based on the method of determining the number of samples according to Morgan, the sample units were 380 MSMEs. While the sample selection method uses non-probability sampling methods. Data collection in this study was carried out using techniques and procedures, namely online questionnaires. Questionnaire is the main instrument in collecting primary data. After the questionnaires were sent to the respondents as many as 400 questionnaires, the next stage was to evaluate the returned questionnaires, namely 380 questionnaires and 20 questionnaires that did not return.

\section{Research Model}

Based on theoretical studies and previous studies, the research model is structured as follows

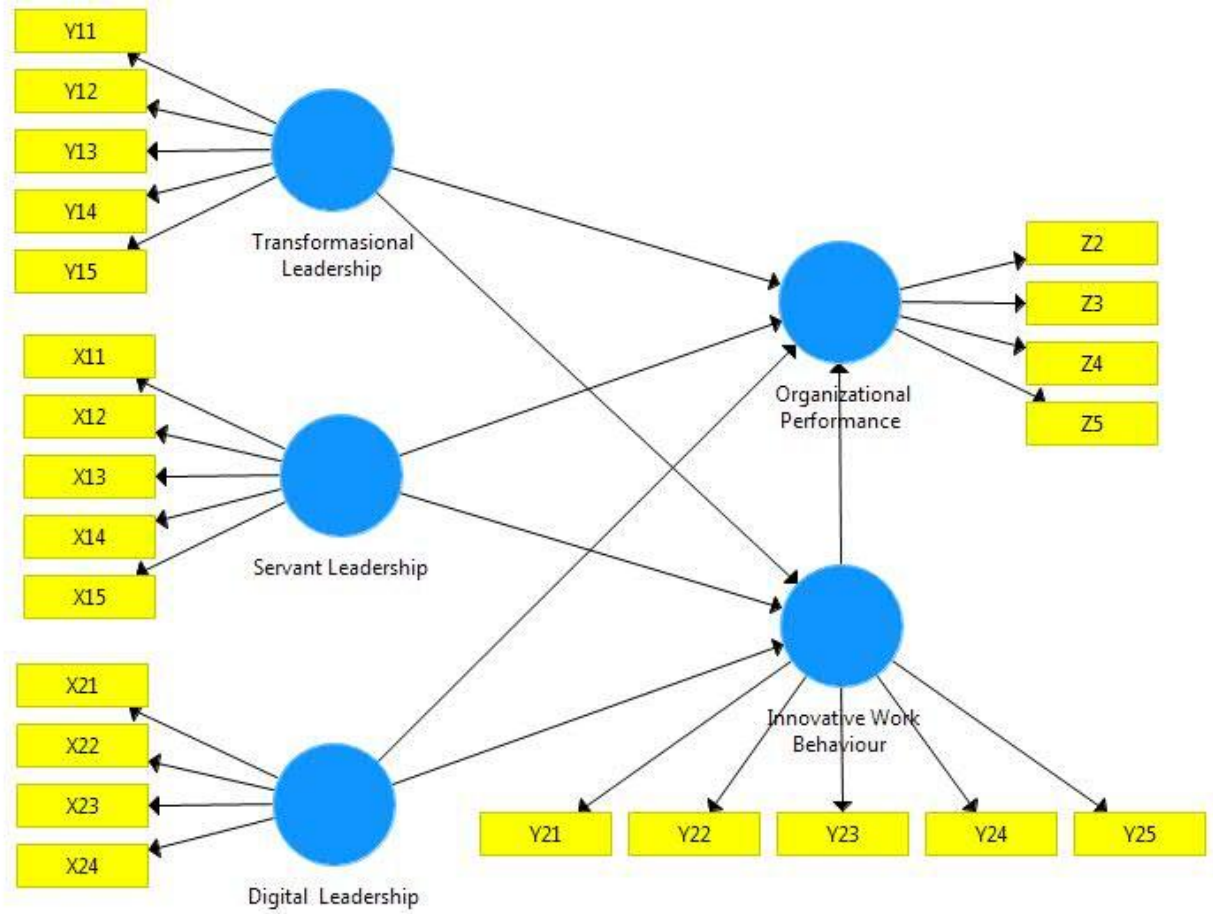

Figure 1. Research Model 
In this study there are 10 hypotheses as follows:

Hypothesis 1: There is a positive influence between Transformational Leadership and Organizational Performance

Hypothesis 2: There is a positive influence between Transformational Leadership and Work Innovation Capabilities

Hypothesis 3: There is a positive influence between Servant Leadership and Organizational Performance Hypothesis 4: There is a positive influence between Servant Leadership and Work Innovation Capabilities Hypothesis 5: There is a positive influence between Digital Transformation and Organizational Performance Hypothesis 6: There is a positive influence between Digital Transformation and Work Innovation Capabilities Hypothesis 7: There is a positive influence between Organizational Performance and Work Innovation Capabilities

Hypothesis 8 : There is a positive influence between Transformational Leadership and Organizational Performance through Work Innovation Capabilities

Hypothesis 9 : There is a positive influence between Servant Leadership and Organizational Performance through Work Innovation Capabilities

Hypothesis 10: There is a positive influence between Digital Transformation and Organizational Performance through Work Innovation Capabilities

\section{Data Processing Stages}

\section{Reliability Test}

According to Purwanto et al (2021) reliability is a measure of the internal consistency of indicators of a construct that shows the degree to which each indicator shows a general latent construct. According to Purwanto et al (2020) the reliability requirement is a measure of the stability and consistency of the results (data) at different times. To test the reliability of the construct in this study used the value of composite reliability. A variable is said to meet construct reliability if it has a composite reliability value $>0.7$ and a Crobanch apha value $>0.7$ has a good level of reliability for a variable (Purwanto et al, 2019).

\section{Validity Test}

After the data test results are declared reliable, then the next step is to test the validity including loading factor, AVE, Farnell Lacker Criterion and cross loading. The steps that need to be taken are selecting the outer loading menu to see the results of the loading factor test, then the discriminant validity menu to see the results of the Farnell lacker criterion and cross loading tests. . According to Purwanto et al. (2020) The validity test is intended to measure the extent to which the accuracy and accuracy of a measuring instrument performs the function of its measuring instrument or provides appropriate measurement results by calculating the correlation between each statement with a total score. In this study, the measurement validity test consisted of convergent validity and discriminant validity.

\section{Convergent Validity}

Convergent validity is used to measure the correlation between item scores and construct scores, the higher the correlation the better the data validity (Purwanto, 2019). Measurement Measurement can be categorized as having convergent validity if the loading factor value is $>0.7$ (Purwanto et al, 2021). If all loading factors have a value of $>0.7$, it can be concluded that all indicators have met the criteria for convergent validity, because no indicators for all variables have been eliminated from the model.

\section{Discriminant validity}

Discriminant validity is a test of construct validity by predicting the size of the indicator from each block (Purwanto et al, 2019). One of the discriminant validity can be seen by comparing the AVE value with the correlation between other constructs in the model. If the AVE root value is $>0.50$, it means that discriminant validity is reached (Purwanto et al, 2020). In addition, discriminant validity is also carried out based on the Fornell Larcker criteria measurement with constructs. In addition to using the AVE value, another method that can be used to determine discriminant validity is to measure discriminant validity by using the cross loading value. An indicator is said to meet discriminant validity if the cross loading value is 0.70 or more (Purwanto, 2020).

\section{Structural model (inner model)}

The structural model (inner model) is a pattern of research variable relationships. Evaluation of the structural model is by looking at the coefficients between variables and the value of the coefficient of determination (R2). The coefficient of determination (R2) essentially measures how far the model's ability to explain variations in the dependent variable is. A value close to 1 means that the independent variables provide almost all the information needed to predict the variation of the dependent variable (Purwanto, 2021). This test aims to determine how much the independent variable model's ability to explain the dependent variable. The value of 
$\mathrm{R}$ square (R2) is a measure of the proportion of the variation in the value of the affected variable which can be explained by the variable that influences it. According to Purwanto et al (2020) if in a study using more than two independent variables, then the adjusted $r$-square (adjusted R2) is used. The value of r square adjusted is a value that is always smaller than $\mathrm{r}$ square. The $\mathrm{R} 2$ value is close to 1 , with the limiting criteria being divided into 3 classifications, namely:

If the value of $\mathrm{R} 2=0.67$ Model is substance (strong)

If the value of $\mathrm{R} 2=0.33$ the model is moderate (medium)

If the value of $\mathrm{R} 2=0.19$ the model is weak (bad)

In this study, the adjusted r-square value (adjusted R2) is used, because it has more than two independent variables.

\section{Hypothesis Testing}

According to Purwanto et al (2021) After a research model is believed to be fit, a hypothesis test can be performed. The next step is to test the hypothesis that has been built in this study. In this case, the bootstrapping method is applied to the sample. Testing with bootstrapping is intended to minimize the problem of abnormal research data. The last step of the test using the smart Pls application is hypothesis testing and is carried out by looking at the results of the bootstrapping value. This test is done by selecting the calculate menu and after that the menu options appear, then select bootstrapping, then the desired data will appear. The following are the results of the data test using bootstrapping. Hypothesis testing in this study can be known through regression weight by comparing the $p$-value with a significance level of $5 \%(\alpha=5 \%)$. The hypothesis is said to be significant if it has a probability value ( $p$-value) $<5 \%$.

\section{Results and Discussions}

\section{Reliability Test}

According to Purwanto et al (2021) reliability is a measure of the internal consistency of indicators of a construct that shows the degree to which each indicator shows a general latent construct. According to Purwanto et al (2020) the reliability requirement is a measure of the stability and consistency of the results (data) at different times. To test the reliability of the construct in this study used the value of composite reliability. A variable is said to meet construct reliability if it has a composite reliability value $>0.7$ and a crobanch apha value $>0.6$ has a good level of reliability for a variable (Purwanto et al, 2019). The composite reliability value of each indicator can be seen in table 1 below

Tabel 1. Reliability

\begin{tabular}{lll}
\hline Variables & Crobanch Apha & Composite Reliability \\
\hline Transformational Leadership & 0.926 & 0.996 \\
\hline Servant Leadership & 0.933 & 0.948 \\
\hline Digital Transformation & 0.995 & 0.939 \\
\hline Organizational Performance & 0.981 & 0.915 \\
\hline Work Innovation Capabilities & 0.926 & 0.939 \\
\hline
\end{tabular}

In table 1 , it can be seen the results of the analysis of the reliability test using the SmartPLS tool which states that all composite reliability values are each greater than 0.7 , which means that all variables are reliable and have met the test criteria. Furthermore, the value of cronbanch's omission also shows that all cronbanch's 'alpa' values are more than 0.6 and this indicates the level of reliability of the variable has also met the criteria.

\section{Validity test}

After the data test results are declared reliable, then the next step is to test the validity including loading factor, AVE, Farnell Lacker Criterion and cross loading. The steps that need to be taken are selecting the outer loading menu to see the results of the loading factor test, then the discriminant validity menu to see the results of the Farnell lacker criterion and cross loading tests. According to Purwanto et al. (2020) The validity test is intended to measure the extent to which the accuracy and accuracy of a measuring instrument performs the function of its measuring instrument or provides appropriate measurement results by calculating the correlation between each statement with a total score. In this study, the measurement validity test consisted of convergent validity and discriminant validity.

\section{Convergent Validity}

Convergent validity is used to measure the correlation between item scores and construct scores, the higher the correlation the better the data validity (Purwanto, 2019). Measurement Measurement can be categorized as having convergent validity if the loading factor value is $>0.7$ (Purwanto et al, 2021). Figure 2 shows that all 
loading factors have a value $>0.7$, so it can be concluded that all indicators have met the criteria for convergent validity, because indicators for all variables have not been eliminated from the model.

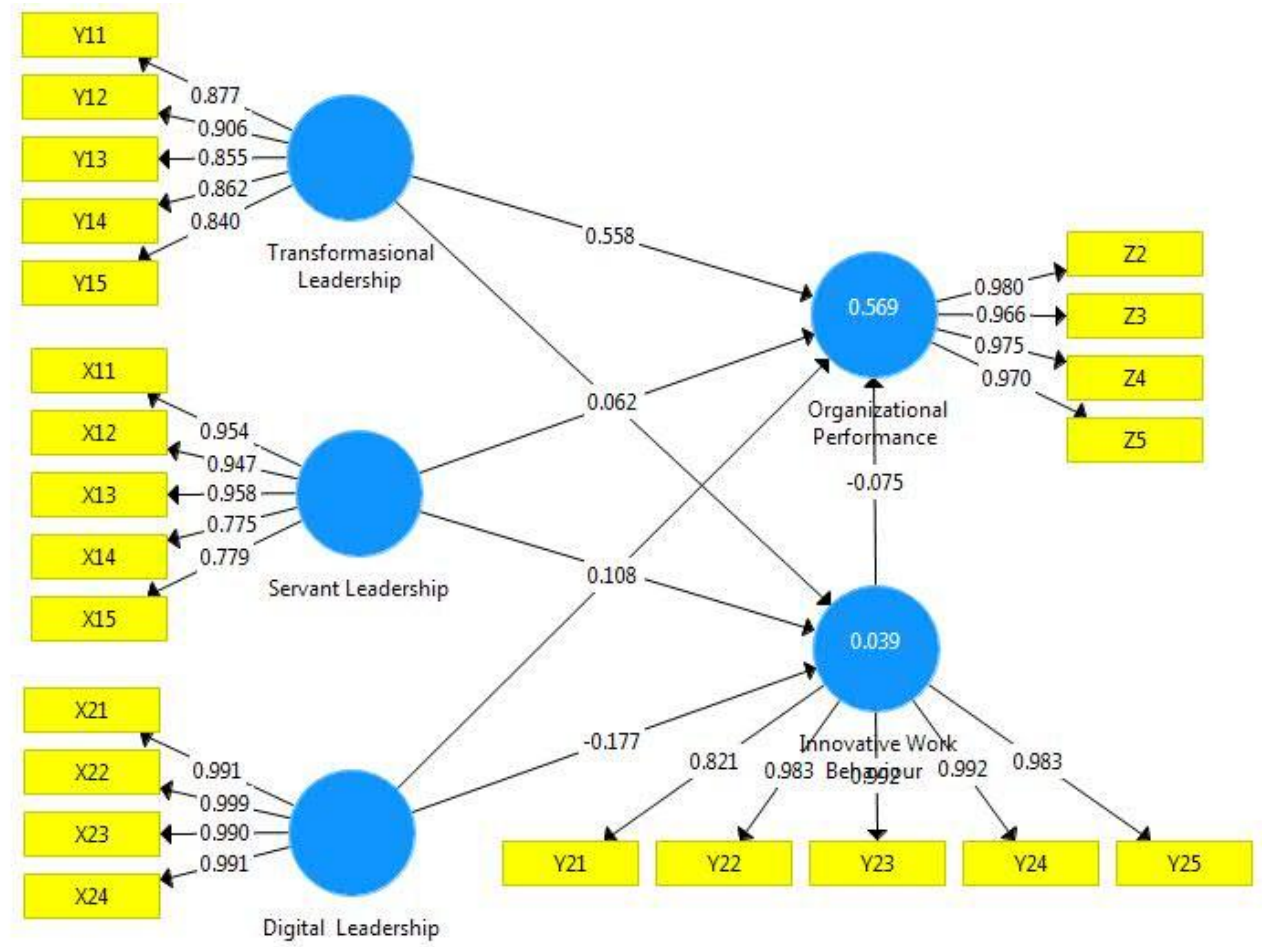

Figure 2. Convergen Validity

\section{Discriminant validity}

Discriminant validity is a test of construct validity by predicting the size of the indicator from each block (Purwanto et al, 2019). One of the discriminant validity can be seen by comparing the AVE value with the correlation between other constructs in the model. If the AVE root value is $>0.50$, it means that discriminant validity is reached (Purwanto et al, 2020).

Based on table 2, the AVE value for all variables is $>0.50$. So it can be said that the measurement model has been valid with discriminant validity. In addition, discriminant validity was also carried out based on the Fornell Larcker criteria measurement with the construct. If the construct correlation in each indicator is greater than the other constructs, it means that latent constructs can predict indicators better than other constructs (Purwanto et al, 2019).

Tabel 2. AVE

\begin{tabular}{ll}
\hline Variables & AVE \\
\hline Transformational Leadership & 0.754 \\
\hline Servant Leadership & 0.786 \\
\hline Digital Transformation & 0.985 \\
\hline Organizational Performance & 0.946 \\
\hline Work Innovation Capabilities & 0.915 \\
\hline
\end{tabular}

\section{Structural model (inner model)}

The structural model (inner model) is a pattern of research variable relationships. Evaluation of the structural model is by looking at the coefficients between variables and the value of the coefficient of determination (R2). The coefficient of determination (R2) essentially measures how far the model's ability to explain variations in the dependent variable is. A value close to 1 means that the independent variables provide almost all the information needed to predict the variation of the dependent variable (Purwanto, 2021). This test aims to determine how much the independent variable model's ability to explain the dependent variable. The value of $\mathrm{R}$ square (R2) is a measure of the proportion of the variation in the value of the affected variable which can be explained by the variable that influences it. According to Purwanto et al (2020) if in a study using more than 
two independent variables, then the adjusted r-square (adjusted R2) is used. The value of r square adjusted is a value that is always smaller than $\mathrm{r}$ square. The $\mathrm{R} 2$ value is close to 1 , with the limiting criteria being divided into 3 classifications, namely:

If the value of $\mathrm{R} 2=0.67 \mathrm{Model}$ is substance (strong)

If the value of $\mathrm{R} 2=0.33$ the model is moderate (medium)

If the value of $\mathrm{R} 2=0.19$ the model is weak (bad)

In this study, the adjusted r-square value (adjusted R2) is used, because it has more than two independent variables.

Tabel 3. r-square adjusted

\begin{tabular}{ll}
\hline Variables & r-square adjusted \\
\hline Organizational Performance & 0.569 \\
\hline Work Innovation Capabilities & 0.039 \\
\hline
\end{tabular}

In table 3 it can be explained that:

The adjusted R2 value of the independent variables Transformational Leadership, Servant Leadership, Digital Transformation on the dependent variable Organizational Performance is 0.569 . This value is categorized as moderate, so it can be concluded that the two independent variables have a moderate influence and level on the dependent variable. The independent variables Transformational Leadership, Servant Leadership, Digital Transformation contributed to the dependent variable Organizational Performance by 56.9\% while the remaining $43.1 \%$ was influenced by other variables not discussed in this study.

The adjusted R2 value of the independent variables Transformational Leadership, Servant Leadership, Digital Transformation, Organizational Performance on the dependent variable work innovation behavior 0.039 . This value is categorized as weak, so it can be concluded that the two independent variables have a bad influence on the dependent variable. The independent variables of Transformational Leadership, Servant Leadership, Digital Transformation, Organizational Performance on the dependent variable of work innovation behavior are $3.9 \%$ while the remaining $96.1 \%$ is influenced by other variables not discussed in this study.

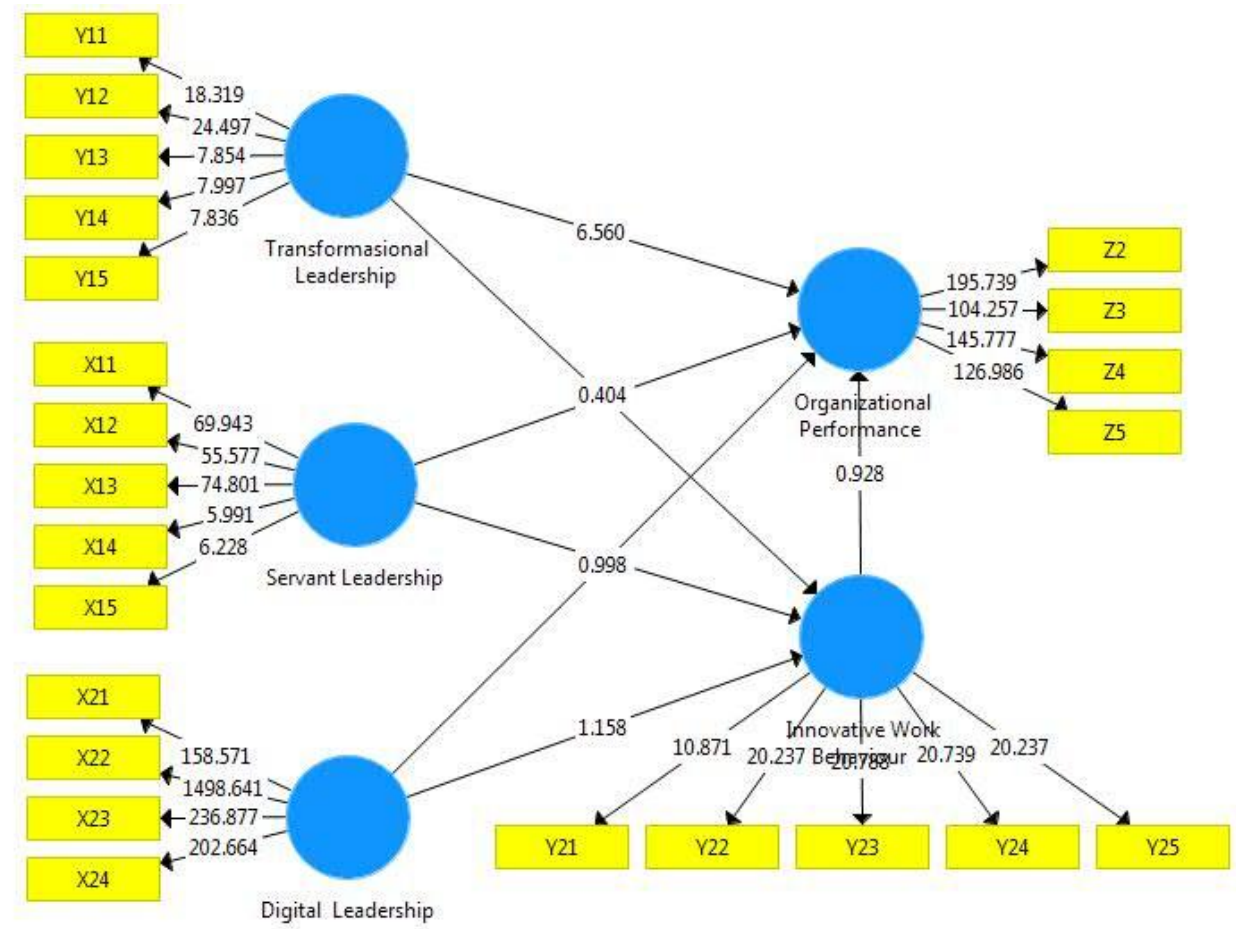

Figure 3. Hypotheses Testing 


\section{Hypothesis test}

According to Purwanto et al (2021) After a research model is believed to be fit, a hypothesis test can be performed. The next step is to test the hypothesis that has been built in this study. In this case, the bootstrapping method is applied to the sample. Testing with bootstrapping is intended to minimize the problem of abnormal research data. The last step of the test using the smart Pls application is hypothesis testing and is carried out by looking at the results of the bootstrapping value. This test is done by selecting the calculate menu and after that the menu options appear, then select bootstrapping, then the desired data will appear. The following are the results of the data test using bootstrapping. Hypothesis testing in this study can be known through regression weight by comparing the p-value with a significance level of $5 \%(\alpha=5 \%)$. The hypothesis is said to be significant if it has a probability value ( $p$-value) $<5 \%$.

Table 4. Hypotheses Testing for Direct Effect

\begin{tabular}{|c|c|c|}
\hline Hypotheses & P - Value & Result \\
\hline $\begin{array}{l}\text { Transformational Leadership }->\text { Organizational } \\
\text { Performance }\end{array}$ & 0.000 & Significant \\
\hline $\begin{array}{l}\text { Transformational Leadership-> Work Innovation } \\
\text { Capabilities }\end{array}$ & 0.684 & Not Significant \\
\hline Servant Leadership-> Organizational Performance & 0.003 & Significant \\
\hline $\begin{array}{l}\text { Servant Leadership-> } \quad \text { Work Innovation } \\
\text { Capabilities }\end{array}$ & 0.297 & Not Significant \\
\hline $\begin{array}{l}\text { Digital Transformation } \quad->\quad \text { Organizational } \\
\text { Performance }\end{array}$ & 0.345 & Not Significant \\
\hline $\begin{array}{l}\text { Digital Transformation->Work Innovation } \\
\text { Capabilities }\end{array}$ & 0.365 & Not Significant \\
\hline $\begin{array}{l}\text { Organizational Performance ->Work Innovation } \\
\text { Capabilities }\end{array}$ & 0.392 & Not Significant \\
\hline
\end{tabular}

\section{Relationship between Transformational Leadership and Organizational Performance}

Based on the results of data analysis using SmartPLS, the $p$ value is $0.000<0.050$ so it can be concluded that Transformational Leadership has a significant effect on Organizational Performance, an increase in the transformational leadership variable will have a significant effect on increasing the Organizational Performance variable and a decrease in the Transformational Leadership variable will have a significant effect on the decrease in the Organizational variable. Performance. This result is not in line with research conducted by El Toufaili (2017), Fayaz (2017), Quddus (2020) that Transformational Leadership has a positive and significant effect on Organizational Performance.

\section{Relationship between Transformational Leadership and Work Innovation Capabilities}

Based on the results of data analysis using SmartPLS, the $p$ value is $0.684<0.050$ so it can be concluded that Transformational Leadership has no significant effect on Work Innovation Capabilities, an increase in the transformational leadership variable will have an insignificant effect on increasing the Work Innovation Capabilities variable and a decrease in the Transformational Leadership variable will have an insignificant effect. to the decrease in the Work Innovation Capabilities variable. This result is not in line with the research conducted by Sheikh et al. (2018); Tsiotsou et al. (2011); Trihas et al. (2013) that Transformational Leadership has a positive and significant effect on Work Innovation Capabilities.

\section{Relationship between Servant Leadership and Organizational Performance}

Based on the results of data analysis using SmartPLS obtained $p$ value of $0.003<0.050$ so it can be concluded that Servant Leadership has a significant effect on Organizational Performance, an increase in the Servant Leadership variable will have a significant effect on increasing the Organizational Performance variable and a decrease in the Servant Leadership variable will have a significant effect on the decrease in the Organizational variable. Performance. This result is not in line with research conducted by Maroukian (2020), Gandolfi (2018) that Servant Leadership has a positive and significant effect on Organizational Performance.

\section{Relationship between Servant Leadership and Work Innovation Capabilities}

Based on the results of data analysis using SmartPLS, the $p$ value value is $0.297<0.050$ so it can be concluded that Servant Leadership has no significant effect on Work Innovation Capabilities, an increase in the Servant Leadership variable will have an insignificant effect on increasing the Work Innovation Capabilities variable and a decrease in the Servant Leadership variable will have an insignificant effect. to the decrease in the Work 
Innovation Capabilities variable. These results are not in line with the research conducted by According to Hernández (2020), Kim (2020). El Toufaili (2017) that Servant Leadership has a positive and significant effect on Work Innovation Capabilities.

\section{Relationship between Digital Transformation and Organizational Performance}

Based on the results of data analysis using SmartPLS obtained p value of $0.345>0.050$ so that it is concluded that Digital Transformation has no significant effect on Organizational Performance, an increase in the Digital Transformation variable will have an insignificant effect on increasing the Organizational Performance variable and a decrease in the Digital Transformation variable will have an insignificant effect on decrease in Organizational Performance variables. This result is not in line with research conducted by Maroukian (2020), Gandolfi (2018), Burawat (2019) that Digital Transformation has a positive and significant effect on Organizational Performance.

\section{Relationship between Digital Transformation and Work Innovation Capabilities}

Based on the results of data analysis using SmartPLS obtained p value of $0.345>0.050$ so it can be concluded that Digital Transformation has no significant effect on Work Innovation Capabilities, an increase in the Digital Transformation variable will have an insignificant effect on increasing the Work Innovation Capabilities variable and a decrease in the Digital Transformation variable will have an insignificant effect. significant to the decrease in the Work Innovation Capabilities variable. This result is not in line with the research conducted by Kim (2020). El Toufaili (2017), Fayaz (2017), Quddus (2020) that Digital Transformation has a positive and significant effect on Work Innovation Capabilities.

\section{Relationship between Organizational Performance and Work Innovation Capabilities}

Based on the results of data analysis using SmartPLS obtained p value of $0.392>0.050$ so it can be concluded that Organizational Performance has no significant effect on Work Innovation Capabilities, an increase in Organizational Performance variables will have an insignificant effect on increasing Work Innovation Capabilities variables and a decrease in Organizational Performance variables will have no effect. significant to the decrease in the Work Innovation Capabilities variable. This result is not in line with research conducted by El Toufaili (2017), Fayaz (2017), Quddus (2020) that Organizational Performance has a positive and significant effect on Work Innovation Capabilities.

Table 5. Hypotheses Testing for Undirect Effect

\begin{tabular}{llllll}
\hline Hypotheses & & & P - Value & Result \\
\hline $\begin{array}{l}\text { Transformational Leadership- Organizational Performance } \\
\text { Innovation Capabilities }\end{array}$ & Work & 0.813 & Not Significant \\
\hline $\begin{array}{l}\text { Servant Leadership -Organizational Performance } \\
\text { Capabilities }\end{array}$ & -Work Innovation & 0.582 & Not Significant \\
$\begin{array}{l}\text { Digital Transformation - Organizational Performance - Work Innovation } \\
\text { Capabilities }\end{array}$ & 0.560 & Not Significant \\
\hline
\end{tabular}

\section{Relationship between Transformational Leadership and Organizational Performance through Work Innovation Capabilities}

Based on the results of data analysis using SmartPLS, the $p$ value is $0.813>0.050$ so it can be concluded that Transformational Leadership has no significant effect on Organizational Performance through Work Innovation Capabilities, an increase in transformational leadership variables will have an insignificant effect on increasing Organizational Performance variables and a decrease in Transformational Leadership variables will provide no significant effect on the decrease in Organizational Performance variables through Work Innovation Capabilities. This result is not in line with the research conducted by Kim (2020). El Toufaili (2017), Fayaz (2017), Quddus (2020) that Transformational Leadership has a positive and significant effect on Organizational Performance through Work Innovation Capabilities.

\footnotetext{
Relationship between Servant Leadership and Organizational Performance through Work Innovation Capabilities Based on the results of data analysis using SmartPLS obtained p value $0.582>0.050$ so it can be concluded that Servant Leadership has no significant effect on Organizational Performance through Work Innovation Capabilities, an increase in the Servant Leadership variable will have an insignificant effect on increasing the Organizational Performance variable and a decrease in the Servant Leadership variable will give no significant effect on the decrease in Organizational Performance variables through Work Innovation Capabilities. This result is not in line with research conducted by Maroukian (2020), Gandolfi (2018) that Servant Leadership has a positive and significant effect on Organizational Performance through Work Innovation Capabilities.
} 


\section{Relationship between Digital Transformation and Organizational Performance through Work Innovation Capabilities}

Based on the results of data analysis using SmartPLS obtained $p$ value of $0.582>0.050$ so it is concluded that Digital Transformation has no significant effect on Organizational Performance through Work Innovation Capabilities, an increase in the Digital Transformation variable will have an insignificant effect on increasing the Organizational Performance variable and a decrease in the Digital Transformation variable will give no significant effect on the decrease in Organizational Performance variables through Work Innovation Capabilities. This result is not in line with research conducted by Fayaz (2017), Quddus (2020) that Digital Transformation has a positive and significant effect on Organizational Performance through Work Innovation Capabilities.

\section{Conclusions}

Based on the results of data analysis, it is concluded that transformational leadership has a significant effect on Organizational Performance, transformational leadership has no significant effect on Work Innovation Capabilities, servant leadership has a significant effect on Organizational Performance, servant leadership has no significant effect on work innovation capabilities, digital transformation has no significant effect on organizational performance, digital Transformation has no significant effect on Work Innovation Capabilities, organizational performance has no significant effect on work innovation capabilities, transformational Leadership has no significant effect on Organizational Performance through Work Innovation Capabilities, Servant Leadership has no significant effect on Organizational Performance through Work Innovation Capabilities, digital transformation has no significant effect significant to the Organization al Performance through Work Innovation Capabilities.

\section{References}

Al Adwan, A., Aladwan, K. M., \& Al-Adwan, A. S. (2019). E-marketing strategic for Jordanian small business to increase sale in local e-market. Academy of Strategic Management Journal, 18(6), 1-13.

Bazazo, I., Alansari, I., Alquraan, H., Alzgaybh, Y., \& Masa'deh, R. E. (2017). The influence of total quality management, market orientation and e-marketing on hotel performance. International Journal of Business Administration, 8(4), 79.

Bui, T. X., Le, T., \& Jones, W. D. (2006). An exploratory case study of hotel e-marketing in Ho Chi Minh City. Thunderbird International Business Review, 48(3), 369-388.

Burawat, P. (2019). The relationships among transformational leadership, sustainable leadership, lean manufacturing and sustainability performance in Thai SMEs manufacturing industry. International Journal of Quality \& Reliability Management.

Chang, H. H., Wang, Y. H., \& Yang, W. Y. (2009). The impact of e-service quality, customer satisfaction and loyalty on e-marketing: Moderating effect of perceived value. Total quality management, 20(4), 423-443.

Cheng, B. L., \& Rashid, M. Z. A. (2013). Service Quality and the Mediating Effect of Corporate Image on the Relationship between Customer Satisfaction and Customer Loyalty in the Malaysian Hotel Industry. Gadjah Mada International Journal of Business, 15(2).

Christopher, A. O. (2021). E-marketing and the hotel business promotion: Prospect and challenges in selected hotels in Ado-Ekiti, Nigeria. E3 Journal of Business Management and Economics., 11(1), 020-026.

El Toufaili, B. (2017). The Effects Of Transformational Leadership On Organizational Performance-A Theoretical Approach. In Proceedings of the International Management Conference (Vol. 11, No. 1, pp. 153-163).

El-Gohary, H. (Ed.). (2013). E-Marketing in Developed and Developing Countries: Emerging Practices: Emerging Practices. IGI Global.

Fayaz, M., \& Shah, S. A. (2017). Relationship between entrepreneurial orientation and firm performance: Moderation of transformational leadership in the context of Pakistani SMEs. Journal of Managerial Sciences, 11(4), 405-420.

Quddus, A., Nugroho, B. S., Hakim, L., Ritaudin, M. S., Nurhasanah, E., Suarsa, A., ... \& Sudargini, Y. (2020). Effect of Ecological, Servant dan Digital Leadership Style Influence University Performance? Evidence from Indonesian Universities. Systematic Reviews in Pharmacy, 11(10), 408-417.

Fernandes Sampaio, C. A., Hernández Mogollón, J. M., \& de Ascensão Gouveia Rodrigues, R. J. (2020). The relationship between market orientation, customer loyalty and business performance: A sample from the Western Europe hotel industry. Tourism and Hospitality Research, 20(2), 131-143. 
Gandolfi, F., \& Stone, S. (2018). Leadership, leadership styles, and servant leadership. Journal of Management Research, 18(4), 261-269.

Gui, L., Lei, H., \& Le, P. B. (2021). Determinants of radical and incremental innovation: the influence of transformational leadership, knowledge sharing and knowledge-centered culture. European Journal of Innovation Management.

Hernández-Perlines, F., \& Araya-Castillo, L. A. (2020). Servant leadership, innovative capacity and performance in third sector entities. Frontiers in psychology, 11, 290.

Hua, N., Hight, S., Wei, W., Ozturk, A. B., Zhao, X. R., Nusair, K., \& DeFranco, A. (2019). The power of ecommerce: Does e-commerce enhance the impact of loyalty programs on hotel operating performance? International Journal of Contemporary Hospitality Management.

Iddris, F., \& Ibrahim, M. (2015). Examining the relationships between e-Marketing adoption and Marketing Performance of Small and Medium Enterprises in Ghana. Journal of Marketing and Consumer Research, 10, 160-169.

Kandampully, J., \& Suhartanto, D. (2000). Customer loyalty in the hotel industry: the role of customer satisfaction and image. International journal of contemporary hospitality management.

Kim, E. J., \& Park, S. (2020). Transformational leadership, knowledge sharing, organizational climate and learning: an empirical study. Leadership \& organization development journal.

Labanauskaitè, D., Fiore, M., \& Stašys, R. (2020). Use of E-marketing tools as communication management in the tourism industry. Tourism Management Perspectives, 34, 100652.

Lim, W. M. (2010). Factor analysis of variables affecting e-marketing adoption by UK independent hotels. In Information and Communication Technologies in Tourism 2010 (pp. 39-50). Springer, Vienna.

Lončarić, D., \& Radetić, N. (2015). The implementation of e-marketing in the hotel industry: The case of Istria county. Zbornik Veleučilišta u Rijeci, 3(1), 12-24.

Maroukian, K., \& Gulliver, S. R. (2020, ). The link between transformational and servant leadership in DevOps-oriented organizations. In Proceedings of the 2020 European Symposium on Software Engineering (pp. 21-29).

Mousavi, S. S. (2012). Effective Elements on E-Marketing strategy in Tourism Industry (Case study: Airlines, Tour Operator and Chain Hotels in Germany and Iran).

Nasihatkon, B., Kheiri, J., \& Miralbell, O. (2016). Social media and hotel e-marketing in Iran: The case of Parsian International Hotels. Turyzm/Tourism, 26(2), 15-21.

Novitasari, D., Haque, M. G., Supriatna, H., Asbari, M., \& Purwanto, A. (2021). Understanding the Links between Charismatic Leadership, Intrinsic Motivation and Tacit Knowledge Sharing among MSME Employees. International Journal of Social and Management Studies, 2(3), 1-13.

Peštek, A., \& Cicic, M. (2010). Application of e-marketing strategies in tourism sector in Bosnia and Herzegovina. In Proceedings, 5th International Conference "An Enterprise Odyssey: From Crisis to Prosperity-Challenges for Government and Business (pp. 132-145).

Purwanto, A. (2021). Partial Least Squares Structural Squation Modeling (PLS-SEM) Analysis for Social and Management Research : A Literature Review. Journal of Industrial Engineering \& Management Research, 2(4), 114 - 123. https://doi.org/10.7777/jiemar.v2i4.168

Purwanto, A., Asbari, M., \& Santoso, T. (2021). Education Management Research Data Analysis: Comparison of Results between Lisrel, Tetrad, GSCA, Amos, SmartPLS, WarpPLS, and SPSS For Small Samples. Nidhomul Haq : Jurnal Manajemen Pendidikan Islam, 6(2), 382-399. https://doi.org/10.31538/ndh.v6i2.1575

Purwanto, A., Asbari, M., \& Santoso, P. B. (2019). Does Culture, Motivation, Competence, Leadership, Commitment Influence Quality Performance?. Inovbiz: Jurnal Inovasi Bisnis, 7(2), 201-205.

Purwanto, Masduki Asbari,Teguh Iman Santoso, Vip Paramarta Denok Sunarsi (2021).Social and Management Research Quantitative Analysis for Medium Sample: Comparing of Lisrel, Tetrad, GSCA, Amos, SmartPLS, WarpPLS, and SPSS.Jurnal Ilmiah Ilmu Administrasi Publik: Jurnal Pemikiran dan Penelitian Administrasi Publik.9(2).518-532

Purwanto,Masduki Asbari,Teguh Iman Santoso,Marissa Grace Haque,Nurjaya (2021)Marketing Research Quantitative Analysis for Large Sample: Comparing of Lisrel, Tetrad, GSCA, Amos, SmartPLS, WarpPLS, and SPSS.Jurnal Ilmiah Ilmu Administrasi Publik: Jurnal Pemikiran dan Penelitian Administrasi Publik.9(2).355-372

Purwanto, A., Asbari, M., Santoso, T. I., Sunarsi, D., \& Ilham, D. (2021). Education Research Quantitative Analysis for Little Respondents: Comparing of Lisrel, Tetrad, GSCA, Amos, SmartPLS, WarpPLS, and SPSS. Jurnal Studi Guru Dan Pembelajaran, 4(2), 335-348. https://doi.org/10.30605/jsgp.4.2.2021.1326

Purwanto, A., Asbari, M., \& Santoso, T. I. (2021). Analisis Data Penelitian Sosial dan Manajemen: Perbandingan Hasil antara Amos, SmartPLS, WarpPLS, dan SPSS Untuk Jumlah Sampel Medium. International Journal of Social and Management Studies, 2(4), $43-53$. https://doi.org/10.5555/ijosmas.v2i4.50 
Purwanto, A., Asbari, M., \& Santoso, T. I. (2021). Analisis Data Penelitian Marketing: Perbandingan Hasil antara Amos, SmartPLS, WarpPLS, dan SPSS Untuk Jumlah Sampel Besar. Journal of Industrial Engineering \& Management Research, 2(4), 216 - 227. https://doi.org/10.7777/jiemar.v2i4.178

Purwanto, A., Asbari, M., \& Santosi, T. I. (2021). Analisis Data Penelitian Manajemen Pendidikan: Perbandingan Hasil antara Amos, SmartPLS, WarpPLS, dan SPSS Untuk Jumlah Sampel Kecil. INTERNATIONAL JOURNAL OF SOCIAL, POLICY AND LAW, 1(1), 111 - 121. https://doi.org/10.8888/ijospl.v1i1.64

Rather, R. A., \& Sharma, J. (2017). The effects of customer satisfaction and commitment on customer loyalty: Evidence from the hotel industry. JOHAR, 12(2), 41.

Salem, I. E. B., El-Said, O. A., \& Nabil, M. (2013). Determinants and effects of applying electronic marketing in Alexandria hotels: Current status and future trends. Journal of Tourism and Hospitality, 2(2), 112.

Siakalli, M., Masouras, A., \& Papademetriou, C. (2017). e-Marketing in the hotel industry: marketing mix strategies. In Strategic Innovative Marketing (pp. 123-129). Springer, Cham.

Singh, A. S. H. O. K., \& Rathore, D. S. (2018). Customers' satisfaction with E-Marketing Tools used by Budget Hotels of Udaipur. South Asian Journal of Tourism \& Heritage, 18(2).

Sheikh, A. A., Rana, N. A., Inam, A., Shahzad, A., \& Awan, H. M. (2018). Is e-marketing a source of sustainable business performance? Predicting the role of top management support with various interaction factors. Cogent Business \& Management, 5(1), 1516487.

Tsiotsou, R. H., \& Vlachopoulou, M. (2011). Understanding the effects of market orientation and e-marketing on service performance. Marketing Intelligence \& Planning.

Trihas, N., Mastorakis, G., Perakakis, E., \& Kopanakis, I. (2013). Efficient e-marketing in tourism through a novel customer relationship management model. GSTF Journal on Business Review (GBR), 3(1), 1-6. 